FIU Law Review

Fall 2008

\title{
Challenging Lies LatCrit Style: A Critical Race Reflection of an Ally to Latina/o Immigrant Parent Leaders
}

Veronica Nelly Velez

University of California, Los Angeles

Follow this and additional works at: https://ecollections.law.fiu.edu/lawreview

Part of the Other Law Commons

Online ISSN: 2643-7759

\section{Recommended Citation}

Veronica N. Velez, Challenging Lies LatCrit Style: A Critical Race Reflection of an Ally to Latina/o Immigrant Parent Leaders, 4 FIU L. Rev. 119 (2008).

DOI: https://dx.doi.org/10.25148/lawrev.4.1.13

This Symposium is brought to you for free and open access by eCollections. It has been accepted for inclusion in FIU Law Review by an authorized editor of eCollections. For more information, please contact lisdavis@fiu.edu. 


\title{
Challenging Lies LatCrit Style: A Critical Race Reflection of an Ally to Latina/o Immigrant Parent Leaders
}

\author{
Veronica Nelly Velez
}

I was nervous as I looked over my notes, preparing to share some preliminary research about Rose Unified's ${ }^{1}$ current schooling dilemmas. As I tried to release some of the tension I felt, I realized that in many ways the information I was about to present, and the forum organized to share it that evening with teachers, school district officials, civic leaders, and school board candidates, was one result of the several years of organizing by ALIANZA $^{2}$ to dismantle institutional constraints to educational opportunities in the Los Angeles area. But it was also information that conveyed a reality from a place of pain as well as hope, from a lived experience of immigrating to the U.S. that deeply understood what injustice meant and why mobilizing for change was so important. This presentation revealed only a piece of ALIANZA's story, one that sought to expose oppressive schooling practices but also one that carefully and intimately reflected a journey of ALIANZA's members from the margin to the center of creating social and educational change. This was evident even in their decision to conduct the event in Spanish and provide translation for the monolingual English speakers in the audience. In the past, when ALIANZA did this, it always promoted a greater sense of confidence and comfort among our Latina/o immigrant ${ }^{3}$ families that translated into an increased participation on their behalf in presentations and dialogues. In essence, ALIANZA was not only defining the content but the terms of

\footnotetext{
University of California, Los Angeles, Graduate School of Education and Information Studies. Actual name of school district has been replaced by a pseudonym.

Actual name of parent group has been replaced by a pseudonym to protect its anonymity. ALIANZA is the Spanish word for "alliance."

3 In this study, Latina/o immigrant refers to both men and women who were born in Mexico, Central America, South America, Cuba, and Puerto Rico. I use this term in the same way that ALIANZA utilizes it, to highlight and capture a shared experience of being both Latina/o and an immigrant in the U.S. It includes individuals with distinct immigration status (i.e. permanent residents, noncitizen, undocumented). It should be noted that the term "Latina/o" has a political dimension that this paper and research project does not address.
} 
engagement for this event, always mindful of how to best facilitate the inclusion of voices so often ignored. After going over my notes for the fifth time, I looked up and realized the room had quickly filled where my presentation was to take place. Clara, one of ALIANZA's parent leaders, motioned me to the front, embraced me and handed me the microphone. I'll never forget her words as I cued my visuals for the presentation: "Acuerda que nunca estás sola, nuestra esperanza vencerá todas las fronteras." tered the room. Their strength filled me and I began the presentation. . 6

The excerpt above, taken from a personal journal entry in February of 2007, details one of the most formative experiences for me as both a future scholar and long-time ally to organizing efforts by Latina/o immigrant parents. It documents an event-a forum to discuss Rose Unified's current problems and introduce school board candidates to community membersorganized by a group of Latina/o immigrant parent leaders known as ALIANZA. This event marked the high point of several months of organizing by ALIANZA to bring issues of concern affecting Latina/o families to the attention of school and civic-appointed leaders before the March 2007 local election. One of the factors that made this forum important and insightful, both personally and for the audience it was intended for, is that it was organized and brought on behalf of Latina/o immigrant parents. Their story, like the many others that I have had the honor to know and work beside during my ten years as a community organizer, is not unique, but rarely told from a critical lens that examines how the intersecting elements of race, class, gender, and immigration status both frame and are challenged by their efforts. In fact, the dominant story in educational research and practice about Latina/o parents generally is one of disinterest, apathy, and disinvestment in education. This perception, I argue, is one of the most deeply rooted and widely accepted lies in educational discourse.

During my recent participation as a presenter at the twelfth annual LatCrit Conference, I had the opportunity to share alongside fellow colleagues a collaborative theoretical project we have been developing around the notion of racist nativism. We began working on this project in an effort

4 Actual names of informants have been replaced by pseudonyms to protect their anonymity.

5 Translated to English, the saying means "Remember, you are never alone, together we will overcome every border."

6 This excerpt was taken from a personal journey I have been using to document my experiences working as an ally with Latina/o families, local non-profit, immigrant advocacy organizations, and community groups. This excerpt, dated February 2007, reflects only my recollections and reflections of the event it describes. 
to better understand and conceptualize the experiences of Latina/o students and families, particularly in an anti-immigrant climate. Using LatCrit as our epistemological and methodological guide, we set out to define the intersection between race and immigration status that both centered white supremacy and was historically situated. Nervous at first to present to a community of mostly lawyers, our theorizing about racist nativism from our perspective as educators and educational researchers was well received by our audience. Their insights have furthered my own research efforts to better understand and define the intersectionality of race and immigration status as it applies to my own work around the efforts of Latina/o immigrant parents striving towards social change.

Although my thoughts about how to apply a LatCrit analysis to the study of parent involvement is a recent endeavor, it is influenced by both my personal and professional trajectories. For several years, I have been working with Latina/o parents, most of whom are undocumented ${ }^{7}$ immi- $^{-}$ grants, to create spaces that facilitate their participation in local politics and school decision-making. Throughout this time, I have come to realize firsthand how institutions, namely schools, could function to marginalize the very communities they blame for not being more involved in education. But some of this realization came earlier. Growing up, I often witnessed how my mother, an immigrant from Mexico, and my father, an immigrant from Panama, struggled to communicate with my teachers because English was not their dominant language, and how they often felt rebuffed by administrators as a result. Despite this, my parents persisted, always asserting their right to have a say in how my schooling was conducted. My parents' involvement in decision-making at my elementary school became so strong that my mother was eventually elected PTA president and, later, hired as the school office manager. And their experiences of navigating U.S. society, through the intersecting structural barriers of racism, nativism, and poverty, in order to provide their children opportunities that had been denied them, became tools, in the form of consejos, ${ }^{7}$ that they utilized to raise and strengthen my sister and me. Their experiences, struggles, hopes, and dreams were no different than those of the parents I had come to work beside as an adult, such as those in ALIANZA. Their stories form an integral part of my theoretical and professional development in this area.

Building from my personal and professional trajectories along with the insight gained from my participation in the LatCrit conference, I began to reflect about how to use LatCrit to begin theorizing about Latina/o immi- 
grant parents as powerful agents of change in schools and society at large, which often fail to recognize them as such. I went in search of literature to help explain the institutional and contextual factors that I argue powerfully shape the experiences of the parents I have worked with. I began searching in the areas of parent involvement and civic engagement, as these areas directly addressed the participation and efforts of the parents I collaborated with. But rather than come across a vast literature in educational research that critically situated and contextually informed the civic and educational efforts of these parents, I instead encountered a wide array of culturally deficit arguments that blame Parents of Color generally, and Latina/o parents specifically, for the failed success of their students in public schools. Within a framework of civic engagement that assumes citizenship, Latina/o immigrants, particularly the undocumented, ${ }^{8}$ are rarely acknowledged as agents of civic change. With some exceptions, my search not only ended up uncovering a void in the educational literature which failed to explain the efforts of groups like ALIANZA but, I argue, also defined parent involvement and civic engagement in such a way that renders such efforts by non-citizens invisible from the start. Referring to the realm of education, Edward M. Olivos highlights this problem when he writes: "The inability of current parent involvement policy and practice to take into account contradictions and tensions in knowledge, culture, and power, particularly in regard to bicultural parents, has contributed greatly to the alienation of these communities from the schooling process."

Thus, in my current effort to explore the work of parents, like those in ALIANZA, from a LatCrit stance, I first had to "unmask" the normative premise of parent involvement and civic engagement work. This article reflects that attempt and argues that LatCrit is necessary to both understanding and challenging the central and intersecting ways race and racism operate to marginalize Latinas/os and, in this case, Latina/o immigrant parents specifically. Below, I begin this process by first defining a LatCrit approach to education. Using this framework, I then deconstruct parent-

8 In this study, undocumented is used to refer to immigrants who come to the U.S. without "proper" documentation that would otherwise grant them legal authority to reside within the borders of the U.S. It is important to note that this label is highly contested. I use this term cautiously, recognizing its problematic nature in defining or framing U.S. immigrants from a nation-state position without adequately recognizing global conditions that have lead many individuals to risk their lives to cross the border without this documentation. I have chosen to use this term in lieu of other terms in public discourse, such as illegal or alien, because these later terms serve to inhumanely criminalize and demonize the immigrant population of concern here, particularly Latina/o immigrants in contemporary U.S. society.

9 Edward M. Olivos, The Power Of Parents: A Critical Perspective Of Bicultural Parent InVolvement In Public Schools 77 (Peter Lang Publishing 2006). 
involvement work and, with the aid of more critical research in the areas of parent involvement and civic engagement, employ LatCrit as a theoretical tool to reconstruct and build a new framework. This intersecting framework of parent and civic engagement centers the voice and experiences of Latina/o immigrant parents in an effort to more fully capture an understanding of their relationship with schools and society.

\section{LATINA/O CRITICAL RACE THEORY IN EDUCATION: ITS ROOTS \& DEFINITION}

Critical Race Theory (CRT) draws from several disciplines, including civil rights, ethnic, and critical legal studies, to examine and transform the relationship among race, racism, and power. ${ }^{10}$ Mari Matsuda defines CRT as:

[T] he work of progressive legal scholars of color who are attempting to develop a jurisprudence that accounts for the role of racism in American law and that works toward the elimination of racism as part of a larger goal of eliminating all forms of subordination. ${ }^{11}$

Thus, CRT is motivated by social justice and characterized by a passionate activism to eliminate racism as part of a broader effort to end subordination on gender, class, sexual orientation, language, and national origin lines. $^{12}$ Some of the basic tenets or themes of CRT include the reexamination of history through the eyes and voices of People of Color and interest convergence, and the belief that racial reform only serves to promote whites' self-interest. ${ }^{13}$

CRT today is characterized by various new sub-disciplines that "challenge civil rights activists to rethink the ways they conceptualize race and civil rights." ${ }^{\prime 4}$ Latina/o Critical Race Theory (LatCrit) is one of those subdisciplines that emerged to explore and deconstruct race-neutral or colorblind ideologies within historical and cultural contexts in an effort to challenge racial and/or ethnic subordination as it particularly affects Latinas/os.

10 Richard Delgado \& Jean Stefancic, Critical Race Theory: An Introduction (Richard Delgado and Jean Stefancic eds., NYU press 2001).

11 Mary Matsuda, Voices of America: Accent, Antidiscrimination Law, and a Jurisprudence for the Last Reconstruction, 100 YALE L.J. 1329, 1331 n.7 (1991), cited in Daniel Solorzano, Critical Race Theory, Race, Gender Microaggressions, and the Experience of Chicano and Chicana Scholars, 11(1) QuALITATIVE STUdies In EDUCATION 121, 122 (1998).

12 Solorzano, supra note 11 , at 122.

13 See generally DERrick A. BELl, SILENT COVENANTS: BROWN v. BOARD OF EDUCATION AND ThE Unfulfilled Hopes For Racial Reform (Oxford Univ. Press US, 2004); Delgado \& STEFANCIC, supra note 10.

14 Delgado \& STEFANCIC, supra note 10, at 101 
Although originating in the field of law, both CRT and LatCrit have crossed disciplinary borders. Within the field of education, for example, these frameworks are providing educational researchers with a lens to explore the role of race and racism in the educational experiences of Students of Color and, in the case of LatCrit, Latina/o students specifically.

It is important to note that LatCrit is not incompatible with CRT. According to Francisco Valdes, "LatCrit is supplementary, complementary to [CRT]. LatCrit . . . at its best, should operate as a close cousin-related to [CRT] in real and lasting ways. ...."15 As a related framework, LatCrit holds the same traditions and purpose of CRT, but was developed to explore issues relevant to Latinas/os when CRT fell short as an analytical lens. Elizabeth Iglesias described the main limitation of CRT as one of scope; namely, that CRT's preoccupation with a black/white paradigm often narrows its ability to adequately answer questions about the role of race and racism, and other forms of oppression, in the lives of Latinas/os, Asian Americans, and other Communities of Color. ${ }^{16}$ Thus, LatCrit, as one of the branches of CRT, has now become an important theoretical lens for legal and other scholars to more fully examine how multiple forms of oppression, based on immigration status, language, culture, ethnicity, and phenotype intersect to shape the experiences of Latinas/os. ${ }^{17}$

One important development in LatCrit, for exploring how these multiple forms of oppression affect Latina/o immigrants specifically, has been the emergence of theoretical work examining the intersection of racism with nativism. ${ }^{18}$ In an effort to explain the recent experiences and attacks against Latina/o undocumented immigrants, particularly of Mexican descent, that led to the mass pro-immigrant mobilizations in the Spring of 2006, Lindsay Perez Huber et al. argued that exploring the intersection of racism and nativism is key to understanding the contemporary experiences of Mexican immigrants in particular, and Latinas/os generally. ${ }^{19}$ Perez Huber et al. use a LatCrit lens to define racist nativism as:

15 Francisco Valdes, Foreward: Latina/o Ethnicities, Critical Race Theory, and Post-identity Politics in Postmodern Legal Culture: From Practice to Possibilities, 9 LA RAZA L. J. 1, 26 (1996).

16 Elizabeth Iglesias, Foreward: International Law, Human Rights, and LatCrit Theory, 28 U. MiAMi INTER-AM. L. REV. 177, 178 (1997).

17 Daniel Solorzano \& Dolores Delgado Bernal, Examining Transformational Resistance Through a Critical Race and LatCrit Theory Framework, 36(3) URBAN EDUCATION 308, 311-12 (2001).

18 Higham defines nativism as the "intense opposition to an internal minority on the grounds of its foreign (i.e. 'un-American') connections." John Higham, STRANGERS IN THE LAND, PATTERNS OF AMERICAN NATIVISM (1860-1925) 4 (Rutgers Univ. Press 3d ed. 1988) (1955).

19 Lindsay Perez Huber, Corina Benvides Lopez, Maria C. Malagon, Veronica Velez \& Daniel Solorzano, Getting Beyond the 'Symptom,' Acknowledging the 'Disease': Theorizing Racist Nativism, 11(1) CONTEMPORARY JUSTICE REVIEW 39 (2008). 
The assigning of values to real or imagined differences, in order to justify the superiority of the native, who is perceived to be white, over that of the non-native, who is perceived to be People and Immigrants of Color, and thereby defend the right of whites, or the native, to dominance. $^{20}$

By deconstructing the racist and nativist premise of notions such as "illegality" and "alien" that frames the current dominant discourse on immigration, work such as that being produced by Perez Huber et al. provides a more critical contextual lens to understand the power dynamics inherent in the subordination experienced by Latinas/os. ${ }^{21}$ Moreover, it provides an important framework for understanding the experiences of foreignness, fear, invisibility, and criminality faced by these same persons. ${ }^{22}$

Exploring these intersections and others within education, LatCrit has further evolved from its roots in legal scholarship. Daniel Solorzano and Tara Yosso define LatCrit theory in education as:

A LatCrit theory in education is a framework that can be used to theorize and examine the ways in which race and racism explicitly and implicitly impact on the educational structures, processes, and discourses that effect People of Color generally and Latinas/os specifically. . . LatCrit scholars in education acknowledge that educational institutions operate in contradictory ways with their potential to oppress and marginalize co-existing with their potential to emancipate and empower. LatCrit theory in education is conceived as a social justice project that attempts to link theory with practice, scholarship with teaching and the academy with the community. LatCrit theory in education is transdisciplinary and draws on many other schools of progressive scholarship.

Similar to a CRT approach in education that has exposed and sought to challenge ways racism mediates to produce educational inequality both in

20 Id. at 10

21 Id.

22 See generally Leisy J. Abrego, Almost American: Life and Educational Experiences of Undocumented Latino Youth, presented at the UCLA Second Annual Interdisciplinary Conference on Race, Ethnicity, and Immigration (May 28, 2002); Leo Chavez, Immigration Reform and Nativism: The Nationalist Response to the Transnationalist Challenge, in IMMIGRANTS OUT!: THE NEW NATIVISM AND THE ANTI-IMmigRant IMPULSE IN THE United STATES (Juan Perea ed., New York Univ. Press 1996).

23 Daniel Solorzano \& Tara Yosso, Critical Race and LatCrit Theory and Method: CounterStorytelling: Chicana and Chicano Graduate School Experiences, 14(4) QUALITATIVE STUDIES IN EDUCATION 471, 479 (2001). 
and out of the classroom, ${ }^{24}$ a LatCrit approach in education employs the following five elements that frame its methodological use within research:

1. The intercentricity of race and racism with other forms of subordination;

2. The challenge to dominant ideology;

3. The commitment to social justice;

4. The centrality of experiential knowledge;

5. The transdisciplinary perspective. ${ }^{25}$

Through these elements, LatCrit allows educational researchers to "see," deconstruct, and transform the racist and intersecting oppressive educational realities that affect Latina/o students and their families. In this way, it has aided my own analysis of parent involvement and civic engagement work that I argue has operated to render invisible the work of individuals and groups like ALIANZA. I now turn to this analysis beginning with a LatCrit deconstruction of parent involvement research and policies.

\section{A LATCRIT ANALYSIS OF PARENT INVOLVEMENT RESEARCH}

A. "Latina/o Parents Do Not Care about Education:" Unveiling the Myth, Challenging the Lie

A broad consensus exists among educational researchers, teachers and school administrators, policy makers, and the public that parent participation is a crucial element in the academic achievement of children and in the overall promotion of school quality. As mentioned in the introductory section of this study, an extensive body of research is now available that has established this strong link. ${ }^{26}$ Along with making this link, the following

24 See generally Solorzano, supra note 11; Solorzano \& Delgado-Bernal, supra note 17; Solorzano and Yosso, supra note 23.

25 Solorzano, supra note 11, at 122-23; Solorzano \& Delgado Bernal, supra note 17, at 312-15.

26 See generally David P. Baker \& David L. Stevenson, Mother's Strategies for Children's School Achievement: Managing the Transition to High School, 59 Sociology OF EdUCATION 156 (1986); J.L. Epstein, Effects on Parents of Teacher Practices of Parent Involvement, Report No. 346, (Center for Soc. Org. of Schools, Johns Hopkins U.) (1983); A NEW GENERATION OF EvidENCE: The FAMILY IS Critical to Student Achievement, (Anne T. Henderson and Nancy Berla eds., 1994); James A. Banks, Multicultural Education: Historical Development, Dimensions, and Practice, 19 REVIEW OF RESEARCH IN EDUCATION 3 (1993); Kathleen Cotton and Karen R. Wikelund, Parental Involvement in Education (2001), available at Northwestern Regional Educational Laboratory, http://www.nwrel.org/scpd/sirs/3/cu6.html; J. CuMMins, NEGOTIATING IDENTITIES: EdUCATION FOR EMPowerment In A Diverse SociETy (1st ed., California Ass'n. for Bilingual Educ. 1996); ConchA 
important argument has also been established in dominant, and well-cited parent involvement work, particularly on Latina/o parents: Latina/o parents do not care about education. ${ }^{27}$

According to R.R. Valencia and M.S. Black, this widespread stereotype or "myth" that Latina/o parents do not value education is based on deficit thinking, in particular culturally deficit arguments that attempt to explain the school failure of Latina/o children. ${ }^{28}$ [First name needed] Pearl explains that cultural deficit or deprivation models "singled out the family unit as the transmitter of deficiencies . . . The family unit-mother, father, home environment-[is] pegged as the carrier of the pathology." ${ }^{29}$ Logically then, if a child fails academically the "deficient" home is to blame. Hence the assumption follows that Latina/o children fail in school because they are not appropriately socialized for academic competence, a direct result from the indifference their parents demonstrate toward education. ${ }^{30}$ The persistent and pervasive academic achievement gap between Latina/o students and their white peers contributes to the perpetuation of such culturally deficit explanations for Latina/o school failure. ${ }^{31}$ The questioning of this assumption in critical research and through historical analyses, however, is beginning to challenge these deficit explanations.

A small body of qualitative and ethnographic research investigating the socialization practices of Latina/o parents reveals a different reality from that posed by the erroneous, deficit claims of their educational apathy.

DElgado-GAITAN, LITERACY For EMPOWERMENT: THE ROLE OF PARENTS IN CHILDREN's EdUCATION (Routledge 1990); CONCHA DElgado-Gaitan, The POWER OF COMMUNiTY: MOBILIZING For FAMILY AND SCHOOLING (Rowman and Littlefield 2001).

27 See generally Ruben Donato, The Other Struggle for Equal Schools: Mexican Americans During the Civil Rights Movement (Univ. of New York Press 1997); R.P. Moreno \& Richard R. Valencia, Chicano Families and Schools: Myths, Knowledge, and Future Directions for Understanding, in CHICANO SCHOOL FAILURE AND SuCCESS: PAST, PRESENT AND FutuRE (Richard R. Valencia ed., Routledge Falmer 2002); Edward M. Olivos, Dialectical Tensions, Contradictions, and Resistance: A Study of the Relationship Between Latino Parents and the Public School System Within a Socioeconomic “Structure of Dominance," (2003) (unpublished Ph.D dissertation, San Diego State Univ./ Claremont Graduate Univ.); in 87(4) The High School Journal 25 (2004); Richard D. Stanton-Salazar, Manufacturing Hope And Despair: The School and Kin Support Networks of U.S.-MeXiCan Youth (Teachers College Press 2001); Guadalupe Valdes, Con Respeto: Bridging The Distances Between Culturally Diverse Families And Schools: AN ETHNOGRAPHIC PORTRAIT (Teachers College Press 1996); R.R. Valencia \& M.S. Black, "Mexican Americans Don't Value Education!": On the Basis of Myth, Mythmaking, and Debunking, 1 JouRnAL OF LATINOS AND EDUCATION 81 (2002).

28 See Valencia \& Black, supra note 27.

29 Arthur Pearl Daniel, Cultural and Accumulated Deficit Thinking, in THE Evolution OF Deficit Thinking: Educational Thought And PRACTICE (Richard R. Valencia ed., The Falmer Press 1997).

30 Moreno \& Valencia, supra note 27.

31 Id. 
In a few studies, researchers have found that Latina/o parents continuously expressed a strong value for the education and academic achievement of their children. ${ }^{32}$ Critical examinations of the Latina/o home have showed that it provides a rich socio-cultural environment of learning, even though these cognitive "spaces" differ from mainstream dominant culture. ${ }^{33}$ Olivos additionally cited several important studies of Latina/o families that demonstrate the multiple ways learning and literacy occur in Latina/o homes, regardless of socio-economic status. ${ }^{34}$

In addition to demonstrating the educational involvement in Latina/o homes, Olivos also provided an important analysis for understanding the relationship between Latina/o parents and public schools. ${ }^{35} \mathrm{He}$ found that Latina/o parents actively resisted, challenged, and even transformed contradictory and "oppressive" school policies and practices. ${ }^{36}$ Jasis \& OrdañezJasis similarly discovered in their study of a Latina/o parent-organizing project at a public middle school that Latina/o parents actively worked to establish a more inclusive partnership with their school. ${ }^{37}$ Both Olivos and Jasis et al. indirectly uncovered institutional processes that served to marginalize Latina/o parents from meaningful participation in schools by demonstrating how Latina/o parents struggled to be validated by school agents as important collaborators in both student achievement and school improvement. $^{38}$

Another important body of work that has made similar arguments to those provided by Olivos and Jasis et al. is the work by Concha DelgadoGaitan, highlighting the efforts of Latina/o immigrant parents in Carpinteria, California. Using socio-cultural theories and Freirean concepts of empowerment, Delgado-Gaitan provided a complex and rich understanding of the personal and collective empowerment of her Latina/o immigrant parentinformants as they organized and developed leadership to address educational concerns in their community. ${ }^{39}$ She poignantly and powerfully documented how Latina/o immigrant families in Carpinteria confronted po-

32 See Stanton-Salazar, supra note 27; Valdes, supra note 27; Valencia \& Black, supra note 27, at 81-103.

33 C. Delgado-Gaitan, supra note 26; Concha Delgado-Gaitan, supra note 26; Valdes, supra note 15 .

34 Edward M. Olivos, Tensions, Contradictions, and Resistance: An Activist's Reflection of the Struggles of Latino Parents in the Public School System, THE High School Journal 25 (April/May 2004).

35 See id.; Olivos, supra note 9; Olivos, supra note 27.

36 See Olivos, supra note 34.

37 Jasis, P. \& Ordoñez-Jasis, R. (2004). Convivencia to empowerment: Latino parent organizing at La Familia. The High School Journal, December 2004 / January 2005, 32-42.

38 See Olivos, supra note 34.

39 See, e.g., DELGADO-GAITAN, supra note 26. 
verty and racism as they organized into a formal group, known as COPLA (translated in English as "Committee of Latino Parents") which provided them agency to navigate the school system and advocate for improvements in their children's schooling. ${ }^{40}$ Her work, I argue, is fundamental and necessary to any investigation of Latina/o immigrant parental involvement both inside and outside of schools.

In addition to scholarly research, R.P. Moreno and Richard Valencia provided a brief historical analysis of the multiple ways Chicana/o parents and families have struggled to provide better education for their youth. ${ }^{40}$ By providing numerous examples of litigation, advocacy organizations, the efforts of multiple individual activists, political demonstrations, and legislation, Moreno and Valencia defiantly debunked the deficit myth that Chicana/o families do not care about education. ${ }^{41}$ One example of these efforts is the 1968 East Los Angeles "blowouts." ${ }^{, 2}$ Commonly cited as a defining moment in the Chicana/o movement, the 1968 East Los Angeles school "blowouts" demonstrate how Latina/o parents were critically involved in the struggle to provide equitable, quality education for their children. ${ }^{43}$ Numerous examples also exist in the area of litigation, where Latina/o parents have brought suit to demand educational equity for their children through the desegregation of schools. Two historical and emblematic examples of this are the 1931 case of Roberto Alvarez v. the Board of Trustees of the Lemon Grove School District ${ }^{44}$ and the 1946 case of Mendez v. Westminster. $^{45}$ These historical efforts on behalf of Latina/o parents not only communicate their high value in education but also clearly demonstrate their invested and engaged pursuit for educational equity. ${ }^{46}$

So how can deficit views of Latina/o parents that wrongly characterize them as apathetic and ambivalent about education continue to persist in light of evidence that demonstrates the contrary? I argue that the fundamental reason is racism. In his own reflections as a parent activist in a Latina/o community, Olivos has asserted that the "relationship between Latina/o parents and the school system is a micro-reflection of the societal ten-

40 Id.

40 Moreno \& Valencia, supra note 27.

41 Id.

42 In 1968, Chicano students used the term "blow-out" as a signal for other students to walk out of their classrooms to protest the lack of attention school officials were giving to the worsening educational conditions of Mexican Americans in East Los Angeles (NLCC, 1996).

43 See Moreno \& Valencia, supra note 27.

44 See generally id.

45 Mendez v. Westminster, 64 F. Supp. 544 (D.C. Cal. 1946).

46 See Solorzano \& Delgado Bernal, supra note 17. 
sions and conflicts in the area of . . institutional racism." ${ }^{, 47}$ He has further contended that this tense relationship:

is negatively affected by the cultural biases . . . inherent within the institution of public education as demonstrated by its historic role of using its power to impose the values and wishes of the dominant culture onto bicultural student and parent populations. ${ }^{48}$

How do cultural bias and institutionalized racism become manifested in the perpetuation of these negative stereotypes of Latina/o parents? I maintain that while Latina/o parents demonstrate a high regard for education and exhibit multiple forms of involvement, their contributions to the education of their children do not "fit" within the white, narrowly-defined middle-class standards of what it means to be a "good" and "involved" parent.

These standards, which have become the "norm" for parent involvement in public schools, serve to dismiss Latina/o parents' values and practices as authentic investment in the education of their children. ${ }^{49}$ According to Moreno and Valencia, "the use of a priori categories regarding the nature of parental involvement have constrained our understanding of [how] involvement can vary in families of different cultures within the United States." I0 I argue that the "failure" of Latina/o parents to display behaviors consistent with these dominant parent involvement standards has contributed to deficit stereotypes that they do not care about education.

The following analysis explores this further by examining the politics of parental involvement in public schools. By applying a LatCrit framework to this analysis, I address how racism is central to understanding why "certain" definitions of what it means to be a "good" parent validate and recognize particular types of cultural capital and dismiss others while framing this racist practice as neutral and "color-blind". A LatCrit analysis is important because it not only explicitly focuses on race and racism for understanding the perpetuation of negative stereotypes of Latina/o parents, but it also challenges the very construct of parent involvement all together. ${ }^{51}$ In order to fully unveil and debunk the myth that Latina/o parents do not care about education, ideologies of parent involvement must be deconstructed using a LatCrit lens to expose the institutional forces that stereotype the relationship between Latina/o parents and public schools.

\footnotetext{
7 Olivos, supra note 34 , at 30.

Id. at 29.

Valdes, supra note 15.

50 Moreno and Valencia, supra note 27, at 242.

51 Solorzano and Yosso, supra note 23.
} 
B. The Politics of Parental Involvement and the Marginalization of Latina/o Parents

While several research studies acknowledge that Latina/o parents do indeed value education they also report that Latina/o parents tend to be less "visible" in their children's schools compared to other non-Latina/o parents. ${ }^{52}$ Following culturally deficit thinking, many practitioners believe efforts need to be made to engage "non-standard" Latina/o families in "standard" or "traditional" methods of parent involvement, from which they are currently absent. 53 These efforts have resulted in family intervention/parent education programs that believe "traditional" parent involvement results in improved student achievement among low-income, minority youth. $^{54}$ These efforts are founded on the premise that Latina/o parents lack the necessary "cultural capital" to be "good" parents. I argue that these programs and most public schools value only one type of "cultural capital" and dismiss other types of "capital" or "cultural wealth" that socially and ethnically diverse parents, in particular Latina/o parents, bring to the educational arena. Before engaging in a critical analysis of Pierre Bourdieu's notion of "cultural capital" and the marginalization of Latina/o parents in schools, it is first important to understand what is meant by "traditional" parent involvement.

C. Parent Involvement and "What Works" Publication of the U.S. Department of Education, 1987

The late 1980s and the 1990s saw a heightened interest in understanding how parents could better support the education of their children. ${ }^{56}$ The strategy, known as parent involvement, took center-stage with the 1987 publication of What Works, published by the United States Department of Education. $^{57}$ In the section entitled "Curriculum of the Home," What Works 27.

52 See Olivos, supra note 34; STANTON-SALAZAR, supra note 27; Moreno \& Valencia, supra note

53 See, e.g., Valdes, supra note 15.

54 Id.

55 Yosso defines cultural wealth as "an array of knowledge, skills, abilities and networks possessed and utilized by Communities of Color to survive and resist racism and other forms of oppression." Yosso's model of cultural wealth, situated within CRT, challenges traditional interpretations of cultural and social capital. It shifts the lens away from a deficit view of Communities of Color as places full of cultural poverty disadvantages, and instead highlights the often unrecognized array of cultural knowledge, skills, abilities and contacts held by socially marginalized groups, which Latina/o groups qualify as for purposes for this essay.

56 See, e.g., Valdes, supra note 15.

57 What Works: Research About Teaching And Learning, Department of Education (2d ed. 1987). 
detailed what parents can do at home to help their children succeed in school. Specifically, it contended that parents need to discuss news, television programs, and special events and observe "routine" for meals, bedtime, and homework, among several other tactics. ${ }^{58}$ In addition to the "Curriculum of the Home," parent involvement also includes participation at the school site in activities such as Parent Teacher Association meetings and school decision-making processes. ${ }^{59}$ The message communicated in What Works is that if "parents of disadvantaged children take the steps listed . . their children can do as well at school as the children of more affluent families." ${ }^{, 60}$ Consequently, if parents do not engage in such behaviors they are placing their child at risk for failure in school.

The prescription of parent involvement that arose from What Works is based on an ideology of education that minimizes institutional responsibility for privileging certain students and disadvantaging others and attributes success or failure to the individual efforts of parents. These parent involvement "standards" have served to locate, within Latina/o families, the causes of children's low academic performance rather than attributing such substandard performance to the unequal resources and practices of the school. The following analysis exposes how this traditional definition of parent involvement has significantly contributed to the stereotyping and marginalization of Latina/o parents in schools by refusing to acknowledge and validate the cultural skills and abilities Latina/o parents employ to support their children's academic success.

\section{Rejecting the "Cultural Wealth" of Latina/o Parents and Families}

While most educational research on this topic seeks to identify how Latina/o parents' lack of power, cultural background, and socio-economic environments contribute to their marginalization in schools, a more critical analysis reveals that things are not so simple or straightforward. In fact, simply identifying these characteristics could easily serve to further reinforce culturally deficient notions about Latina/o parents. A more critical analysis finds that embedded in the erroneous argument that Latina/o parents do not participate and do not care about education are racist ideologies that privilege white, middle-class forms of involvement and "cultural capital" while devaluing and rejecting others. Before analyzing how this occurs, a brief understanding of the notion of "cultural capital" is required.

\footnotetext{
$58 \quad I d$.

59 Moreno \& Valencia, supra note 27.

$60 I d$. at 32
} 
According to Richard Arum and Irenee Beattie, cultural capital, first introduced by Pierre Bourdieu, can be defined as possessing those "dispositions, attitudes, and styles" that are characteristic of "upper-class cultural forms." ${ }^{61}$ The more one possesses these attitudes or style, the greater one's cultural capital. $^{62}$ According to Annette Lareau and Erin Horvat, both membership in higher social classes and being white are forms of cultural capital that are immediately validated in school contexts. ${ }^{63}$ Schools value this cultural capital because its possession implies large vocabularies (in English, I submit), time, transportation, and ability to arrange for child-care to attend school events during the day. ${ }^{64}$

While Bourdieu's notion of cultural capital assumes that low-income Parents of Color lack the "capital" necessary to effectively interact with schools, a critical race application of his theory reveals how racism mediates to discount other forms of cultural wealth. ${ }^{65}$ In their research on cultural capital in family-school relationships, Lareau and Horvat argue that while all parents have cultural capital to invest in different settings, not all forms of cultural capital have the same value in a given field. ${ }^{66}$ Specifically, they discovered that "the rules of the game" that mediate the interactions between parents and school are race-specific, whereas white, middle-class parents have what Lareau calls "home advantage". 67 The association of valued "cultural capital" to being white creates a racist-power differential where Latina/o parents' cultural wealth, as manifested in their own investments in education, is deemed inferior by traditional parent involvement measures.

The practice of validating only certain forms of cultural capital is reinforced by the adoption of narrow definitions of parent involvement in schools and in educational research. These narrow guidelines for how to be a "good" parent are problematic when applied universally. ${ }^{68}$ For Latina/o

61 Richard Arum \& Irenee R. Beattie, The Structure Of Schooling: Readings In The Sociology Of EduCATION 4 (Mayfield Publishing Co. 2000).

$62 I d$.

63 See Annette Lareau \& Erin McNamara Horvat, Moments of Social Inclusion and Exclusion: Race, Class, and Cultural Capital in Family School Relationships, 72 Soc. OF Educ. 37, 42 (1999).

64 Id.

65 See Tara J. Yosso, Whose Culture Has Capital? A Critical Race Theory Discussion of Communtiy Cultural Wealth, 8 RACE AND ETHNICITY EDUC. 69, 70 (2005); Daniel G. Solorzano, Octavio Villalpando \& Leticia Oseguera, Educational Inequities and Latino/a Undergraduate Students in the United States: A Critical Race Analysis of Their Educational Progress, 4 J. HISP. HIGHER EdUC., 272, 286 (2005).

66 Lareau \& Horvat, supra note 63.

67 See generally Annette Lareau, Home Advantage: Social Class and Parental InTERVENTION IN ElEMENTARY EdUCATION (Rowman and Littlefield Publishers) (1989); Lareau \& Horvat, supra note 63.

68 See Lareau \& Horvat, supra note 63; Valdes, supra note 15. 
parents, who often utilize consejos and cuentos $^{69}$ to motivate and support their children, these rigid definitions dismiss their forms of investment and contribute to their being labeled as uninterested and disinvested in education. $^{70}$ The failure to recognize multiple forms of Latina/o parent involvement in education creates an environment where Latinas/o parents are frequently rebuffed by administrators and teachers, not included in school discussions about their children, and even less included in school decisionmaking processes. ${ }^{71}$ They are perceived to lack the necessary "cultural capital," as measured by parent involvement standards, to effectively advocate for their children in school. Latina/o parents are therefore dismissed and marginalized and invited only to participate in parent education activities that help them build the "appropriate" capital to be "good" parents. For many Latina/o parents, the dismissal of their contributions often leads to a sense of inferiority, shame, embarrassment, and helplessness, ${ }^{73}$ while others are angered into resisting the lack of respeto ${ }^{74}$ schools demonstrate towards them.

Olivos has maintained that the "absence" of Latina/o parents in schools is more a demonstration of resistance than a sign of disinterest. ${ }^{75}$ He has found that Latina/o parents have valid reasons for refusing to attend parent-involvement "opportunities", usually education workshops that attempt to "improve" Latina/o parenting. ${ }^{76}$ Not only do Latina/o parents find these activities useless, some also perceive them as patronizing and disrespectful. ${ }^{77}$ Further research is needed to explore how the lack of Latina/o parent presence within schools can also be a form of resistance.

In sum, standards of parent involvement found in schools and perpetuated by educational research are narrowly defined, which leads to the exclusion of Latina/o parents and others whose forms of involvement and "cultural capital" are not recognized by educational institutions. According to Olivos, the racism Latina/o parents experience in local schools reflects broader institutionalized structures that negate the value of non-white cultures. $^{78}$ These racist ideologies reject the cultural wealth and educational

69 Cuentos is the Spanish word for stories.

70 Moreno \& Valencia, supra note 27; Valdes, supra note 15.

71 See Susan Auerbach, "Why Do They Give the Good Classes to Some and Not to Others?". Latino Parent Narratives of Struggle in a College Access Program, 104 TCHRS. C. REC. 1369, 1381 (2002); Olivos, supra note 34; Valdes, supra note 15.

72 See Valdes, supra note 15.

73 See, e.g., DELGADO-GAITAN, supra note 26.

74 Respeto is the Spanish word for respect

75 See Olivos, supra note 34.

76 Id.

77 See OLIVOS, supra note 9; Olivos, supra note 34; Valdes, supra note 15.

78 OLIVos, supra note 9; Olivos, supra note 34. 
contributions of Latina/o parents, allowing culturally deficit arguments of Latina/o parents to persist in light of evidence that demonstrates the contrary. I now turn my attention to providing a LatCrit analysis of California's policies on parent involvement, particularly within the realm of educational accountability.

\section{TOWARD A CRITICAL PARENT ENGAGEMENT FRAMEWORK}

In the argument I provided above, a LatCrit framework was essential to a deconstruction of the premise of parent involvement, as made evident in dominant research and policy on the topic, in order to unveil its racist and classist assumptions. But more importantly, LatCrit has become an important tool to acknowledge and place center-stage the efforts of those parents, highlighted by the work of Olivos, Delgado-Gaitan, and Jasis \& Ordañez-Jasis, and those still yet to be documented, such as ALIANZA, within an appropriate critical context. By allowing us to see beyond the normative assumptions in parent involvement work, LatCrit, in conjunction with the research produced by these individuals, helps us begin to understand how Parents of Color generally, and Latina/o parents specifically, engage both the figurative and literal spaces afforded them in schools to bring about change. In essence, it's a call to move from a parent involvement paradigm to one of parent engagement.

In defining parent engagement in contrast to parent involvement, I contend that a parent-engagement approach in educational research recognizes the importance of the relationship between the activities and strategies employed by parents to exert their voice and the context that affects, informs, and may even be contested by such efforts. In other words, it acknowledges how ideology works to shape the very spaces that parents either come to occupy or are marginalized from in schools. This is in contrast to a notion of parent involvement that connotes an idea that parents work to involve themselves within generally accepted spaces, such as parent-teacher associations, or in generally accepted forms, such as those outlined by the 1987 publication of What Works, noted above. The focus within a parentinvolvement paradigm, I argue, is toward solely examining the participation, or lack thereof, of parents without adequately examining how broader mechanisms are at play that have a direct influence on this participation. By shifting to a more critical parent-engagement framework, research becomes more attuned to capturing the important connection between what parents do, in terms of educational reform, and the context in which they do it. It recognizes that parents, particularly working class Parents of Color, engage and may even seek to transform the racist, classist, and/or nativist spaces often allocated for them in schools in order to create the change they hope to see for their children and communities. This also includes efforts to 
create new spaces to more effectively carry out their intentions and efforts. This type of framework is consistent with a LatCrit approach that calls on educational researchers to examine the important contextual elements, such as race, class, and gender that are necessarily crucial to understanding the experiences and efforts of Communities of Color, particularly Latinas/os.

\section{A LATCRIT ANALYSIS OF CIVIC ENGAGEMENT}

Recently, both educators and educational researchers have been called to prioritize the notion of civic engagement in their work. The American Educational Research Association (AERA), one of the most important nationwide networks within the field of education, decided to organize their 2008 national conference under the theme of "Research on Schools, Neighborhoods, and Communities: Toward Civic Responsibility."79 In establishing the importance of this topic, Dr. William Tate, current AERA President, commented that civic responsibility in education is important in bringing a community together to "accept the charge of creating highquality educational opportunities irrespective of neighborhood or other geospatial considerations." ${ }^{80}$ In other words, educational efforts should be invested in civic engagement, or rather defined as a form of civic engagement, as a way of creating a viable path towards educational opportunity.

For many parents trying to exert change in their communities, this intersection between the civic and educational realm is a critical one. Since its inception, ALIANZA's campaign for educational justice has led them into city-wide campaigns that address issues such as affordable housing, economic development, residential segregation, and sustainable employment, among other issues. They are rarely absent from Pasadena City Council meetings, and in November 2007 became one of the lead groups convening a large forum to address how city and school leaders can work more effectively for Pasadena Unified students. The forum, aptly titled "Civic Investment in Our Public Schools," was well attended by more than 200 community residents, school officials, and city leaders. It was one of many efforts, with ALIANZA explicitly reminding city officials that schools are intimately connected to other civic institutions and, therefore, necessarily impacted by civic decision-making.

In this forum, as in other events organized by ALIANZA, the goal was two-fold: (1) to achieve a comprehensive solution towards an equitable education for all children, and (2) to establish all parents as necessary actors within intersecting civic and educational arenas. This is not unlike the

79 http://www.aera.net/meetings.

80 Id. at para. 2 
efforts of parents in Chicago and other U.S. cities, which I briefly highlight below, who have fought and continue to fight for the right of all parents to vote in school-wide elections as part of larger, continuing campaigns to extend suffrage to non-citizens. What makes these efforts and those of ALIANZA particularly significant is that they are spearheaded by and on behalf of immigrant parents, all of whom are non-citizens, and a large proportion of whom are undocumented. In a powerful way then, the civic efforts of these parents are redefining the very meaning of civic engagement beyond the traditionally recognized relationship of the citizen to the state, in which dominant notions of civic engagement derive their value.

It is here that a LatCrit analysis of civic engagement becomes important for this study. Not only does a LatCrit lens provide us an analytic tool to deconstruct the underlying ideologies informing a traditional understanding of civic engagement, particularly from a racist/nativist standpoint, but also aids us in reconstructing this concept from the very experiences of parents. This latter objective heeds the call of Dr. Tate and others to find ways to develop and support the civic efforts of school communities towards educational reform and can powerfully reshape our view of Latina/o immigrant parents, particularly those undocumented, as agents of civic change.

Toward this end, I begin by briefly locating the present study within a larger debate about the meaning of citizenship, which I argue broadly frames a dominant understanding of civic engagement as primarily the work of citizens, via traditional methods such as voting. The intent here is to briefly provide a LatCrit analysis to the notion of citizenship, in order to elucidate its contested meaning and provide a space to illuminate and explore the work of parents, like those in ALIANZA, as that of civic engagement. After this, I provide the example of immigrant parents in Chicago and other U.S. cities to which I alluded above, immigrant parents who are operating from the intersection of civic and parent engagement to claim their right to vote in school-wide elections. These examples highlight how Latina/o immigrant parents, specifically those considered undocumented or non-citizens, are redefining and reclaiming a civic role in electoral politics through their role as parents, regardless of how law or policy defines their position within a U.S. political community. Finally, I conclude with the only study to date that directly examines the efforts of undocumented Latina/o immigrant parents from the place of civic engagement, ${ }^{81}$ and I conclude this article with final thoughts about the urgency of a critical analysis,

81 John Rogers et al., Civic Lessons: Public Schools and the Civic Development of Undocumented Students and Parents, 3 NW J. L. \& Soc. Pol'y 201 (2008). 
like that provided by LatCrit, to support the social justice work of Latina/o immigrant communities.

\section{A. Contextualizing the Civic Engagement of Latina/o Immigrant Parents}

As a way of articulating an understanding of civic engagement in contemporary U.S. society, James Youniss et al. begin by defining civic competence as "an understanding of how government functions, and the acquisition of behaviors that allow citizens to participate in government and permit individuals to meet, discus, and collaborate to promote their interest within a framework of democratic principles." ${ }^{, 82}$ I highlight this definition as representative of a dominant or typical understanding not only of what civic engagement means but for whom it is intended. As Youniss et al. point out, the acquisition of political behaviors geared towards civic participation in a democratic community is the responsibility of citizens. ${ }^{83}$ Although they do not define who exactly is captured by this term, I argue that there is an implicit understanding of what a citizen means in relation to citizenship that reflects a commonly understood and often unspoken assumption.

In her work that seeks to understand the dilemmas and contested meanings of membership in contemporary society, Linda Bosniak nicely summarizes the normative assumptions about citizenship. She argues that:

Most such discussions presume that citizenship is enacted within bounded national societies. Ordinarily, these presumptions are unspoken and unacknowledged: theorists tend to treat both a national setting and a state of boundedness as already satisfied conditions for the practices and institutions and experiences of citizenship. ${ }^{84}$

Thus, a citizen is normatively understood as an exclusive member within a bounded national community. This is not to say that this notion or concept has not been contested. As Bosniak has pointed out, numerous directions in political and legal thought on the subject have lead to a rethinking and redefinition of the concept. ${ }^{85}$ Developing notions of multicultural, corporate, post-national, and cultural citizenship are a few examples of this trend calling for a more universalistic frame of the term. ${ }^{86}$ What is important here is not detailing what each of these new terms means but

82 James Youniss et al., Youth Civic Engagement in the Twenty-First Century, 12(1) J. OF RES. ON ADOLESCENCE 121, 124 (2002).

83 See id.

84 Linda Bosniak, The Citizen And the Alien: Dilemmas of CONTEMPORARy Membership 5 (Linda Bosniak ed., Princeton Univ. Press 2006).

85 See id.

86 See id.; Hiroshi Motomura, Americans in Waiting: The Lost Story of Immigration AND CitiZENSHIP IN THE UNITED STATES (Oxford University Press 2006). 
rather understand that they have all attempted to deconstruct and redefine the very borders or boundaries that have confined traditional notions of citizenship.

These challenges offer powerful insights about how the legally delineated borders that define inclusion or exclusion within a U.S. political community are racially constructed. Although he doesn't explicitly define his work as critical race scholarship, Hiroshi Motomura, for example, argues that race has always been an important part of defining restrictions in U.S. immigration law and policy. Extending this idea, William Flores has underscored how Communities of Color, particularly Latinas/os, have been deprived of certain rights, despite their prominent and long-standing presence within the U.S. ${ }^{87}$ By arguing that citizenship rights are not bestowed but must be fought for and achieved, Flores essentially exposed how the boundaries of citizenship are ridden with racist assumptions that are then challenged in an effort to gain civil rights. ${ }^{88}$ This argument led Flores to define cultural citizenship as the "process by which subjugated groups define themselves, claim space, and claim rights." $" 89$ His work not only rejected what he defined as the "artificial" boundaries delineating who is and who is not a citizen, but it also called for a redefinition of citizenship that emerges from the experiences of marginalized groups, a method that functions in appropriate LatCrit fashion.

Taking Flores' plea seriously, I believe that much can be gained, both theoretically and practically, in exploring how to practice and further civic engagement outside the bounds of citizenship by centering our analysis on the civic efforts of non-citizen parents. Many examples exist, most notably the efforts on behalf of non-citizen parents to obtain voting rights. Below I provide some of these examples in an attempt to build a critical framework to understand the civic engagement of Latina/o immigrant parents, particularly those considered non-citizen or undocumented.

\section{B. Toward a Model of Civic Engagement for Latina/o Immigrant Parents}

In 1988, Chicago's school code was changed to allow all community residents and parents of children in schools, regardless of citizenship, to vote in school-wide elections. Although the campaign to reform Chicago's school code was fought on numerous fronts, much of the leadership was comprised of non-citizen parents. Their voices, among others, were lis-

87 See William V. Flores, New Rights: Undocumented Immigrants and Latino Cultural Citizenship, 30(2) LATIN AM. PERSP. 87 (2003).

88 See id.

$89 I d$. at 96. 
tened to and validated as Chicago determined that the betterment of the future of its schools rested in part in having all parents participate in electoral politics at the school level. This was unlike the reasoning provided in New York, when that city similarly decided to allow non-citizen parents the right to vote in school board elections and to hold office on school boards until 2003..$^{90}$ But during the period that noncitizen parents had the right to vote, Guillermo Linares, who served as president on one of the New York City school boards, acknowledged that this type of action "celebrates and assists the newest wave of immigrants, who are vital to New York City's future as their predecessors." ${ }^{, 11}$ Although not specific to just parents, other campaigns to secure non-citizen voting in local elections have been successful in Maryland and Massachusetts. ${ }^{92}$ The success of these campaigns has helped paved the way for other parent groups seeking to obtain voting rights in their own districts and cities.

One such case is San Francisco. There, as in Chicago, parents organized in 2004 to secure the right to vote in school board election for all parents, regardless of citizenship or "legal" status in the U.S. A local newspaper that reported on the issue when it first emerged interviewed several noncitizen parents in the city for their perspective. ${ }^{93}$ Berta Hernandez, a Mexican immigrant and mother of two children, commented, "[Voting] is not the key to solve all of our problems, but it's an important political tool to help us continue with the fight to have better schools for our children. ${ }^{, 94}$ Miguel Perez, another parent interviewed, referred to the democratic idea of "no taxation without representation" as the reason why all parents should have the right to vote in school-wide elections, since all, regardless of citizenship status, pay taxes. ${ }^{95}$ Although the proposed amendment to the San Francisco school code that would have extended this right to vote did not pass, it hasn't deterred continued efforts to secure non-citizen voting there and elsewhere in the country. In 2005, New Yorkers have once again taken up the campaign to secure the right of non-citizens to vote, but this time in local elections. This is all part of a much broader, emerging immigrantrights movement that is witnessing a proliferation of immigrants' rights

90 Ronald Hayduk, Democracy for All: Restoring Immigrant Voting Rights in the U.S., 26(4) NEW PoL. SCI. 499, 514 (2004).

91 Id. at 515.

92 Id. at 519.

93 Jessie Mangaliman, S.F. May Give Non-Citizens School Board Voting Rights, SAN JosE MERCURY NEwS, June 21, 2004, at A1.

94 Id.

95 Id. 
organizations working to civically engage within an array of issues such as labor, housing, education, health, welfare and foreign policy. ${ }^{96}$

Regardless of whether or not non-citizen immigrant parents were able to secure the right to vote in school-wide elections within their communities, their actions are nonetheless crucial. Not only do they pave the way for furthering future efforts in the same arena, but they also help educational researchers theorize about the important intersection between parent and civic engagement, particularly when it comes to undocumented, immigrant parents. I argue that their efforts can help us better articulate how parent engagement is essentially a form of civic engagement. Additionally, they can help reveal how opportunities to become engaged as parents, both inside and outside of schools, open doors to opportunities for developing civic capacity and leadership.

Only one study to date has begun to theorize about this intersection particularly as it applies to undocumented parents. John Rogers et al. looked at multiple ways that undocumented parents were civically engaged, specifically in the Los Angeles area. ${ }^{97}$ In the qualitative portion of their study, they examined several community organizations that were working toward involving more immigrant parents in educational politics. They found that among all the organizations they surveyed, undocumented parents "participate robustly in educational reform and related civic activity." This includes activities such as attending school-wide meetings, and serving on school and district-governing councils. ${ }^{99}$ They found that an important entry into undocumented parent/civic engagement was through different forms of parent-education structures where they learned important skills about how to communicate their concerns and interests to the broader community, including key stakeholders. ${ }^{100}$ Finally, they discovered that undocumented parents were participating in the electoral process in multiple ways by informing voters door-to-door about school board candidates, making calls to registered voters during election days, and helping to register new voters in their communities. ${ }^{101}$ Taken as a whole, the authors of the study argued that the when "undocumented parents become engaged in their children's school, they both contribute to the school and to their own civic development. ... [S] uch engagement creates new relationships of trust in the broader community [and] . . energize[s] civic action."

96 See Hayduk, supra note 92.

97 See Rogers et al., supra note 83.

98 Id.

99 See id.

100 See id.

101 See id.

102 Id. at 27. 
Because Rogers et al. powerfully exposed the intersection of parent and civic engagement for undocumented parents, it serves as the most important piece of educational research, as it begins to build a critical model for understanding the role of Latina/o immigrant parents, particularly those undocumented, in the arena of civic reform. Moreover, it positions the civic efforts of parents like those in ALIANZA as crucial and important to the overall health of a U.S. democracy and thus, from a LatCrit lens, directly challenges the racist/nativist discourse that undocumented immigrants, particularly Latinas/os, are a "drain" or detriment to U.S. society.

\section{Conclusion: Challenging Lies to Build Movements}

From the work of Rogers et al. and the other examples I provided above, I contend that a model is beginning to emerge to illuminate the educational and civic efforts of Latina/o immigrant parents. Yet, I argue that such a model needs to be embedded within a critical framework, like LatCrit, in order to acknowledge the contextual factors, particularly racist nativism, that I argue necessarily influence these efforts. But there is another important reason why a LatCrit analysis is so critical here. The continued racist perception or lie that Latina/o parents are apathetic about the education of their children is so deeply embedded in educational discourse and practice that critical work, like that being produced by Rogers et al. or Olivos, is the exception and not the norm within our field of research. This translates into an under-acknowledgement and lack of support of efforts toward social justice on behalf of Latina/o families.

Mobilizing to challenge erroneous deficit perceptions about Latina/o parents in an attempt to support their efforts at educational and civic change is crucial in the contemporary moment, where Latinas/os are rapidly becoming the majority in public schools. In 2003, the Study of Latina/o Health and Culture conducted at UCLA predicted that by 2006, the majority of children entering kindergarten in California will be Latina/o; by 2014, the majority of children in high school in California will be Latina/o; and by 2019 , the majority of youth adult voters in California will be Latina/o. ${ }^{103}$ Since this study was published, Latinas/os have indeed become the majority group entering kindergarten in California public schools. In the 2006-2007 school year, Latinas/os comprised $53 \%$ of the kindergarten population. ${ }^{104}$ Although this study originally predicted a 2014 date for when Latinas/os would become the majority in California high schools, recent statistics

103 Hayes-Bautista, David E., LA NuEva CALIFornia: Latinos In THE GOLDEN STATE (University of California Press 2004).

104 http://dq.cde.ca.gov/dataquest. 
posted by the California Department of Education reveal that in 2006 Latina/os already comprised $44 \%$ of the overall high school population and nearly half, $48 \%$, of all students in public schools. ${ }^{1 \%}$

Coupling these statistics with efforts to remedy an increasing number of "under-performing" schools and a rise in an "opportunity gap" ${ }^{106}$ makes all the more urgent the need to support the efforts of Latina/o families within educational and civic spaces for improving schooling conditions. ${ }^{107}$ As Latinas/os rapidly become the majority in California's public schools, finding ways to increase the Latina/o parental voice in school and civic reform is not only important, but essential to (1) better serve the needs of Latina/o students and their families, and (2) create democratic collaborations among schools and their communities for the purpose of improving the educational outcomes of Latina/o children. This is particularly important among Latina/o immigrants, particularly those undocumented, who are often seen as outsiders to the process of school and civic reform.

The beauty of LatCrit is that it goes beyond that of traditional, theoretical frameworks. It requires its proponents to engage and/or further project for social justice and change. Thus, a project of challenging deficit thinking using a LatCrit framework, such as the perception that Latina/o parents don't care about education, must be aimed at a larger project of dismantling all forms of societal subordination. As I continue to reflect on my experiences as a first-time presenter at the LatCrit conference, I am reminded that building such a movement can only be done in the community. The LatCrit conference affords a powerful, anti-racist, and liberating space to have productive conversations about what is needed to build social movements. The space I was provided to share and offer dialogue has been crucial to my development and will continue to form a part of my thinking as I continue to theorize about how to use LatCrit as not only an anti-racist endeavor, but also as a social movement-building project.

105 Id.

106 Here I am borrowing from the report issued by Oakes et al., infra note 107, to define "opportunity gap" as the disproportionate distribution of "opportunities to learn," such as qualified teachers, facilities that are not overcrowded, appropriate learning material, etc., between schools in affluent, White neighborhoods and schools in poor, Communities of Color.

107 See Jeannie Oakes et al., Separate and Unequal, 50 Years after Brown: California's Racial “Opportunity Gap”, INST. FOR DEMOCRACY, EDUC., AND ACCESS (2004). 